\title{
SUSTAINABLE DEVELOPMENT - PROBLEMS OF MEASUREMENT AND POSSIBMLITIES OF REALISATION (CASE STUDY OF NORTH - EASTERN ESTONIA)
}

\author{
Raivo Vilu, Tiina Randla \\ Tallinn Technical University, Chair of Biochemistry, \\ Ehitajate tee 5, Tallinn, EE 0026, Estonia
}

In the middle of the century the exponentially growing mankind lived according to the popular slogan of the Mitchurin - do not ask, take from the Nature everything you need. However, environmental problems we currently encounter indicate that the carrying capacity of the Earth might be soon exhausted. Our environmental consciousness has developed from the "silent spring" through the "Limits of the Growth" to the present concept of the sustainable development. If in 70-ies the main problem seemed to be the limitation of the resources, then now reasonable management of the Earth, the development of harmonious existence of the manking in the Nature is in the focus. It means that much attention is paid to defining in quantitative terms what kind of management, resource use, style of life is sustainable. Long lists of quantitative parameters, indicators of sustainability have been proposed $(1,2)$. Generally speaking the use of indicators should make complicated systems understandable and predictable, to show to the society, where we are, where we are going and how to intergrate different subsystems of noosphere into a sustainable wholeness. The development of adequate set of indicators is feasible only if the noosphere is described using well-founded and syncretic system of models. One of the main goals in the nearest future would probably be formulation and analysis of the hierarchical set of models of the sustainably developing Earth, models where the "climate engine" of the planet and global economy are considered as one integrated system.

The indicators of sustainability are usually divided into four main classes - economic, environment, social sphere and government. The main difference between the indicators of sustainable development and traditional indicators of the state of environment, social welfare etc. is 
the complex nature of the new indicators - they are "normalized" and "calibrated". New indicators are based as a rule on instrumental measurements or stastical analysis what makes them objective. We should not forget also that they must be very practical - indicators of no practical use have no practical value. They must help in our turning towards the trajectory of sustainable development. The indicators should be applicable globally but at the same time they should take into account the local (national) peculiarities. For example - the increasing birth rate is negative at the global scale but an attractive goal for Europe and especially Estonia. Some of the indicators are based on the use of the notion of "balanse" - exploitation of resources and the self - regenerative processes. Emission of pollutants should not exceed the adsorption capacity of environment etc. In some cases we act globally, for example we all use oxygen and produce $\mathrm{CO}_{2}$ which are parts of one global reservoir - atmosphere. In these cases introduction of the notion "global environmental space" is well justified. At the same time fresh water is considerably more local resource (which, however, depends on the functioning of global "climate engine"), and the water use should be balanced locally (appropriate parameter "calibrated" on the local "space"). Problem of calibration is very complicated in some cases due to the need to take into account also "social justification". For example, in what extent the greater use of energy in the cold climate of North-Europe in comparison with Africa, living in the conditions of eternal summer, is "socially" (rationally?) justifiable.

Principles of the sustainable development of Estonia are legitimised by the "Law of sustainable development" (adopted by the Parliament February 22nd, 1995). However, the law is too declarative and needs to be amended in the near future. It is quite difficult to make practical amendments without taking into account logins of indicators of sustainability.

A very interesting separate problem is associated with making industry (industrial areas) more sustainable. These problems have been considered recently in the framework of industrial ecology. A reasonable solution here is the creation of so called eco-industrial parks, where the members of the consortia are effectively using wastes generated by the others which enables to increase the economic efficiency of the complex and to decrease the total production of wastes (3).

However, development of such symbiotic structures is currently not automatically profitable and leads frequently to economic losses. Our 
economic system with the set of taxes and prices is not taking into account the principles of sustainability. Another problem which should be pointed out is that engineers are not yet accustomed to think in categories of industrial ecology. The symbiotic relationship can be developed only in the eco-industrial parks, associations of closely connected enterprises-taking these considerations into account would mean adoption of new principles of regional planning. It is not easy.

As is well-known, various large enterprises are concentrated in Northeast of Estonia-oil shale mines, power stations, chemical enterprises etc. Production of these enterprises is extremely important from the point of view oe the economic welfare of the republic - $100 \%$ of electrical power used in Estonia is produced in power plants of the region. Unfortunately the powerful industrial complex is also a huge polluter. In 1995, for example, 74 thousand tons of $\mathrm{SO}_{2}, 12$ thousand tons of $\mathrm{CO}_{2}$ and 68,3 thousand tons of solid wastes were generated by the power plants (4). There are specialists who think that the sustainable management and development of the Estonian oil shale industry is impossible and the only reasonable decision would be the planned (controlled) liquidation of this industry. At the same time, as far as we know, nobody had studied the opportunities for the development of symbiotic consortia of the enterprises in the region, where the maximum economic benefit would be obtained with the minimal amount of wastes. Just the opposite could be said. As an example it should be reminded that the use of the ashes produced by the combustion of oil shale in thermal power plants in agriculture and production of building materials was stopped in 1993 in the result of the collapse of the former economic system. In 1990 the amount of ashes used for these purposes was about 2,5 million tons. (5).

The aim of the present study is the analysis of the "meaning" and applicability of different indicators of sustainability and problems associated with their "calibration". An attempt to develop system of indicators and to explore the possibilities for the decrease of the iosses of resources and pollution in the result of the integration of enterprises of north-eastern Estonia (already existing and new ones) into a symbiotic eco-industrial park to attain the sustainable development of Estonia will be made. 


\section{Literature}

1. Hart - Hart , Environmental Data - Indicators of Sustainability, 1996 http://www. Subjectmatters.com/indicators/Indicators.html

2. CIAT-UNEP Environmental and Sustainability Indicators. Potential Spatial Indicators, May 1996 - http://www.ciat.cigar.org/land/indicators/ gisorg.html

3. http://www.indigodev.com:80/Cases.html

4. Keskkond 1995. Eesti Vabariigi Keskkonnaministeerium, Info - ja Tehnokeskus, Tallinn, 1996.

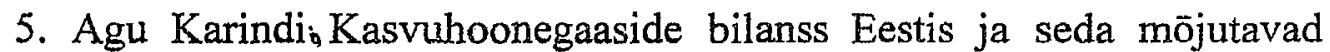
faktorid. Magistritoo Tallinna Pedagoogikaūlikool, Juhendaja prof. J-M Punning, Tallinn, 1996. 